\title{
Of Innocuousness and Insolence: A Dialogue on Commitment in Nigerian Drama
}

\author{
Desen Jonathan Mbachaga \\ http://dx.doi.org//10.4314/ujah.v17i1.9
}

\section{Abstract}

Questioning repression and exploitation especially of the working class is the hallmark of committed writing. This paper looks at the relevance of literature or art to life with a focus on the Nigerian experience. Our commitment as dramatists is to capture socio political experiences in our environments by clearly expressing the anxieties and sensibilities of our societies. The paper submits that the committed dramatist is one who knows his history and refuses to bow to the hegemonic structures of the system (status quo). Also, our writings as dramatists and artistes must not just offer mere social criticism but expose the social institutions in our communities and countries at large by properly delineating the conflicts and struggles between individuals and social classes. The paper concludes that, for our writing and indeed art to find relevance and make impact on the teeming population, it must provide 'hope' through reminding the world of a need to re - humanize with a focus on loving ourselves as humans, comforting ourselves and caring for ourselves.

Key words: committed writing, Nigerian Drama, arts for art's sake.

\section{Introduction}

Art must not merely mirror reality, but make audiences question values as categories of the status quo. David Krasner (2008:3)

The search for relevance of literature or art to life has triggered many ideological debates that engage intellectuals 
who question power relations in society. One can therefore submit that, the profound verity and social significance of art in relation to ideas is that it dares to question 'something', power, society. The inherent character of art as a tool for upholding human dignity and promoting freedom of thought and expression become paramount as creative works, especially drama, is used by writers to affirm humanism by breaking the back bone of oppression, dominance and exploitation.

Thus, committed art is art that breaks the silence by audaciously taking a crack at questioning social happenings and powers that be - status quo. The implication herein is that, the 'mutual silence' from our pens as writers and groups regarding social happenings around us must be broken. This means we stand out against the social and or political structures that stand against the true essence of human development. This requires us as dramatists, to write in a constructive manner to question repression and exploitation especially of the working class and increase the awareness of the people - masses regarding their knowledge or idea of self. It is imperative therefore, that as dramatists, we capture socio political experiences in our environments by clearly expressing the anxieties and sensibilities of our societies with a view of drawing attention to the deplorable health conditions, corruption in high places, greed, insecurity and other vices that negatively affect the well being of the masses for the benefit of few political elite. The words of Tanure Ojaide (2011:6) strongly project this as he submits that:

... what are writers in countries with 'sit-tight' presidents doing about the governance of their states? Have writers not become too silent in the face of power, too soft and distracted by other considerations to speak truth to power? 
Contemporary African writers have to responsibly create texts that advance the vision and ideals of their respective communities.

The above attitude locks up writers in silos making their works merely arts for arts' sake. Art that does not question the system and does not reflect the socio political realities of its community is moribund or "has a 'huge hole' and is a Sunday distraction for somnambulist petit bourgeoisie; transient art, which like bubble gum, is chewed, enjoyed, and spat out" (Amatoritse Ede cited in Ojaide 2011:1).

The obligation herein is for art that is used to promote or achieve social change. This is the social duty of the artiste and or writer. The functional role of theatre therefore, is to feed the audience (spectators) with undiluted milk of truth. Silence in this instance is not the answer rather pushing towards utilizing our art and indeed theatre to draw attention to and pushing towards solving the social problems of society. Theatre here is not content with merely entertaining but serves the purpose of sifting and laying bare before the audience the 'sickness' inherent in the society. Suffice it to say that, theatre as art has fought battles that addresses questions of life and is rooted in socio political issues affecting the people. This is because, theatre on the Nigerian scene looks at social relations and political transformations in the society. The human essence is made manifest through theatre because the artiste reflects the mores, values, aspirations, as well as failures.

The core issue here is for writers to continually highlight social problems by focusing on social maladies and unambiguously confronting the masses with real socio political events so as to question class structures that are oppressive and exploitative. In the words of Gbilekaa ( 1997: $\mathrm{xi)}$ :

This will (should) take us beyond mere analysis of content and form in our chosen plays. We will take 
into consideration the very art of creativity itself. This will entail posing such questions as who do our playwrights create for, why do they create the way they do, what issues are addressed in their plays? (Emphasis mine)

Herein, the function of theatre beyond entertainment and the pursuance of theatre as a sheer aesthetic endeavor for entertainment is addressed. The writer here pokes, prods, and points the way out of the quagmire of life. Staring from the distance is not the answer here rather promoting human dignity and pride is the focal point of every committed writer and artiste. Every committed writer shoulders this responsibility of guiding, giving voice and being the conscience of his society. Jean Paul Satre (1947) in expounding his notion of committed literatures underscored these hard facts of oppression and exploitation of the masses. He felt a writer's responsibility lies in addressing this anomaly. Thus, this forms his beliefs regarding ethical concerns and the social responsibility of the artist as well as intellectuals.

The relevance of our art herein lies in the fight for democratic space for writers and artistes. Where freedom of speech and expression is pushed to the ground or locked behind Bars and sometimes murdered. What the system promotes is a bunch of praise singers who eat the crumbs or leftovers from the political elites table and cannot speak back at the system. This set of writers have compromised and sold out to the system and can no longer pose the questions of life and human relations at the system.

Ngugi wa Thiongo's struggles in Kenya readily come to mind. He was a professor of Literature at Nairobi University when he was imprisoned. The reason for this was his use of community theatre to engage ordinary people 
regarding their history of anti - colonial struggle as well as; contemporary social conditions in post colonial Kenya. Upon release as a result of pressure from the National and international community he was barred from employment in the country of his birth for daring to empower Kenyan peasants.

In Nigeria Hubert Ogunde, Wole Soyinka, Ken Saro Wiwa and Fela Anikulapo Kuti have at various times suffered brutality and imprisonment at the hands of the system for voicing out against the neo colonial military regime in Nigeria. Saro Wiwa eventually was murdered for having the courage to willingly speak up against the status quo regarding issues of political significance in relation to the people of Ogoni Land. Soyinka in his pursuance of his vision of social liberation, projects these issues in his plays Kongi's Harvest, Mad Men and Specialists, A Play of Giants, The Jero Plays and especially in The Road where he indicts the social, political, economic as well as moral crisis in Nigeria. Soyinka through the character of Joe exposes the corruption and rottenness of the police and makes strong comments regarding the chasm between the few elites who are privileged and the people they exploit. Duro Ladipo's Oba Koso and Hubert Ogunde's Yoruba Ronu also capture issues of misrule, leadership failure and corruption. Ogunde is remembered for his astute "commitment to truth and exposure of anti social behaviors of the powers - that - be, colonial and civilian" (Obafemi 1996:37). Sunnie Ododo in his play Hard Choice (2011) "makes distinct statements regarding the issue of ethnic diversity and its effect on nation building. The play concentrates on ethnic tolerance, and the issue of ethno regional domination which has remained the greatest challenge in post-independence Nigeria and a strong influence affecting the stability of the Nation. As such Ododo in this play projects a meditational philosophy of nationalism hinged 
on peaceful co - existence among the various ethnic groups. Suffice it to say that; the play provides a comprehensive study on the historical and socio - political realities which it articulates" Mbachaga (2012:127).

More recently, Victor Dugga in his play A Bridge of strings (2005) creatively confronts socio political issues in Nigeria and places his search light on tyranny, corruption and social disorder as well as leadership issues. Bakare Ojo Rasaki cannot be left out among contemporary writers because he has continued to sound the trumpet to increase the anxiety of oppressive regimes in a bid to expose their crimes against the people. His plays Once upon a Tower (2001), This Land Must Sacrifice (1991), Rogbodiyan (1995), The Gods and the Scavengers (2006), lucidly and fearlessly capture socio political events that expose corruption, leadership ineptitude and economic failings in the Nigerian state. Keneth Eni entered the scene of Nigerian playwrights with his play $A$ Taste of Violence (2012) where he portrays an abnormal culture of armed robbery gangs that haunt and torment the society. In the play, the robbers accuse the wealthy elite and government of neglecting the poor. Eni explores several reasons why young people involve in robbery and brings to fore the fact that, society creates these monsters out of neglect and omissions. Within the scope of this play, Eni examines the failures in society through the characters of Stella, Spencer, Ricky and Obaro who are members of a gang of robbers. In the words of Stella; "criminality is the product of oppression and exploitation..." (A Taste of Violence 28). However, he suggests hope for the nation through the character of Biokoro who turns a new leaf and refuses to be part of the gang even though the gang feels betrayed by him. This aspect in the world of the play arouses optimism that the rot has not overtaken all. At least, some persons still have the courage to refuse and reject criminality. The validity and topicality of this 
play reminds us of the daily challenges of the Nigerian youth and the varying influences on his character and decisions which have given rise to unemployment and high crime rates in our society. Eni shows through the conflicts in the play that society needs to reexamine its sense of values if it wants to correct and stem the spate of crimes.

From the above, we can say that the committed dramatist who utilizes his pen to interrogate the socio political and economic issues in a bid to promote positive values and ideals is not insolent; rather, he promotes human ideals of peace, equity, justice, tolerance, love and so on. Thus, the committed dramatist is one who knows his history and refuses to bow to the hegemonic structures of the system (status quo). He is one who gives voice to the voiceless by conveying the yearnings and aspirations of the people especially the marginalized, oppressed and exploited. This is an ethical imperative for Nigerian dramatists and writers as a whole.

The core issue here is the role of the dramatist and or writer, his intellect showing concern to the plight of the people by capturing the essence of the moment in history with his creativity and pen. His writing and art becomes the vehicle for articulating and interpreting the realities of his environment and presenting alternative options that can erstwhile solve the problem. This is re-echoed by Ngugi Wa Thiongo ( 1997: xvi) who says;

Literature cannot escape from the class power structures that shape our everyday life. Here, a writer has no choice. Whether or not he is aware of it, his works reflect one or more aspects of the intense economic, political, cultural and ideological struggles in a society. What he can choose is one or the other side in the battle field: the side of the people, or the side of those social forces and classes 
that try to keep the people down. What he or she cannot do is to remain neutral. Every writer is a writer in politics. The only question is what and whose politics.

Ngugi here calls on writers to create works that project the economic and political struggles between the dominating class and the dominated. The dominant class being the ruling elite; while the majority, who are poor and landless peasants, who are brutally exploited and struggle to barely survive. Our literature and indeed art must therefore strive to expose anti humanist forces in a bid to improve the value and quality of human lives.

In this light, our writings should and or must not necessarily be seen as primarily literary or aesthetic expressions but texts that represent social reality. This goes to say that our writings as dramatists and artistes must not just offer mere social criticism but expose the social institutions in our communities and countries at large by properly delineating the conflicts and struggles between individuals and social classes. The above position is the prevailing view of the artiste in the society which is socio - political. A role, that calls on the artiste or writer to use his art and creativity to enhance change in the society. Here the writer's work becomes a tool in mass education and stimulation for action. The action referred to here is that which can broaden the quality of life among humans. The writer's 'voice' therefore re - echoes social needs and aspirations as he makes up 'new voices' from events around him to broaden knowledge and give social commentary on issues thereby becoming a teacher and guide to society who tries to salvage the collapse of social affairs.

This 'collapse' calls the writers humane side which makes him choose between silence that leads to self denial 
and insolence which pitches him or her against the system and powers that be thereby making him or her voice for the voiceless. This kind of commitment derives from the belief that as writers, our duty is to uphold moral principles. This he achieves by seeking to point out truth in his writings that will fight what is perceived as oppressive regimes and dictatorship in leadership which has been the focus of some Nigerian writers and makes them to be branded as rebels especially when they threaten oppressive regimes. Wole Soyinka, ended up in prison several times for his writings; while Fela Anikulapo Kuti lost his mother for voicing out against the status quo and several others who have been silenced or forced to exile for confronting the gods of our society.

Iorwuese Hagher (2004: 47) aptly submits that,

All writings embody themes and world views. A writer's theme and world view determines whether he can serve as the conscience of his or her society; whether he has taken the sides with the victim or the predator. As the conscience of the society, the role of the writer is to be in league with the victim. This role is to help the victims of society recover from being preyed upon, and more than that to take control of her destiny to reassert her active participation. To do this the writer must have the right philosophical perspective of society, from which the writer interprets reality.

As Hagher advises above, the new writer must seek in his writing to defend the poor and voiceless. His pen must serve the interest of the countless victims of exploitation and oppression and class of predators in capitalist states which Ngugi (1997: 47) describes as "a system of the robber and the robbed". The robbed been the masses who are victims of the 
system hijacked by the rich who ensure that the poor is removed from the picture by removing his right and freedom such as freedom of speech, freedom to vote and be voted for, right to good wages and so the poor masses remain tamed and resign themselves to the condemned fate by the opressors completely disempowered. Our writing as dramatists, novelists and poets in Nigeria therefore must not necessarily romance the system thereby choke the society with the ideas and values of the dominant class but the themes and values should confront the dominant class and make them uncomfortable and increase their anxiety so as to make the oppressors and exploiters know that their deeds are been seen.

There is an urgent need to reawaken the conscience of the world through our writings and art to make them see the values that once held us together and made us humane; the value for life, the value of brotherhood and love for fellow humans that was enshrined in the philosophy of been your brother's keeper, respect for truth and equity and justice among others. A lack of these values or loss of same has robbed us of the very essence of our humanness and consequently removed the care and love we once shared as Nigerians and indeed Africans. The absence of these Values has seen our world crumble and turn to a place where conflicts abound with innocent people becoming victims of religious and ethnic wars. The way out is a reorientation towards our moral ideals which our intellectuals in their creativity and art are required to commit themselves to teaching and projecting in their works.

Innocuous writing and creativity betrays the responsibility and moral obligation of giving direction and stimulating the conscience of the society. It rather, genuflects and pays obeisance to the exploitative powers and silently accepts their handouts stolen from the tax payers as gratification for a conscience mortgaged for personal gain and 
generations continue to suffer Infectious diseases, injustice, exploitation and oppression from corrupt and kleptomaniac political elite. Not to forget the strangulating effect of corruption and tribal vengeance while western entrepreneurs with whom the post colonial predators have an alliance, hungrily share our resources as our cultural base is torn to bits and pieces.

We can therefore conclude that for our writing and indeed art to find relevance and make impact on the teeming population it must provide 'hope' through reminding the world of a need to re - humanize with a focus on loving ourselves as humans, comforting ourselves and caring for ourselves, only then will our art do what we have been searching for - a transformed world with selfless, noble people of noble actions who have the interest of mankind at heart in spite of themselves.

Desen Jonathan Mbachaga Department of Theatre and Media Arts Federal University Oye Ekiti, Nigeria

\section{References}

David, Krasner. (2008). "Introduction" In Theatre in Theory 1900 - 2000: An Anthology. David Krasner (Ed). USA. Blackwell Publishing.

Gbilekaa, Saint. (1997). "Introduction" In Radical Theatre in Nigeria. Ibadan: Caltop Publications.

Hagher, Iorwuese. (2004). Weapons of Mass Instruction:

Selected Speeches \& Essays on Politics, Art \&

Leadership. Ibadan: Spectrum Books.

Kenneth, Eni. (2012). A Taste of Violence. Ibadan: Temple Publications. 
Mbachaga, Desen. (2012). Managing Diversity; Promoting Nation Building and Peace in Nigeria: a Critical Reading of Sunnie Ododo's Hard Choice. in A Gazelle of the Savannah: Sunday Ododo and the Framing of Techno Cultural Performance in Nigeria. Osakue S. Omoera, Sola Adeyemi, Benedict Binibai (Eds). United Kingdom: Crown Publishers.

Ngugi, Wathiong'o. (1997). Writers in Politics. Portsmouth: Heinemann.

Obafemi, Olu. (1996). Contemporary Nigerian Theatre:

Cultural Heritage and Social Vision. Lagos: Centre for Black and African Arts and Civilisation (CBAAC).

Tanure, Ojaide. (2011). "Homecoming: African Literature and Human Development". Key Note Address at the $30^{\text {th }}$ Annual ANA International Convention Abuja. 